\title{
Hydrologic Monitoring Plan of the Brazilian Water Producer/PCJ Project
}

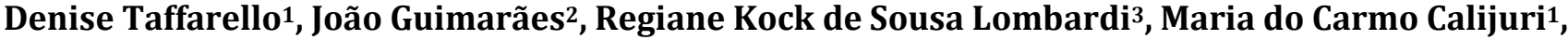 Eduardo Mario Mendiondo 1,4}

${ }^{1}$ Hydraulics \& Sanitary Department, Escola de Engenharia de Sao Carlos, University of Sao Paulo, Sao Carlos, Sao Paulo, Brazil

${ }^{2}$ Fauna and Flora International, Biodiversity Partnership, Curitiba, Paraná, Brazil

${ }^{3}$ Lombardi Topografia e Agrimensura, Curitiba, Paraná, Brazil

${ }^{4}$ Brazilian Center of Monitoring and Early Warning of Natural Disasters (CEMADEN), Sao Jose dos Campos, Sao Paulo, Brazil

Email: taffarellod@gmail.com

How to cite this paper: Taffarello, D., Guimarães, J., de Sousa Lombardi, R.K., do Carmo Calijuri, M. and Mendiondo, E.M. (2016) Hydrologic Monitoring Plan of the Brazilian Water Producer/PCJ Project. Journal of Environmental Protection, 7, 1956 1970.

http://dx.doi.org/10.4236/jep.2016.712152

Received: June 2, 2016

Accepted: November 27, 2016

Published: November 30, 2016

Copyright (c) 2016 by authors and Scientific Research Publishing Inc. This work is licensed under the Creative Commons Attribution International License (CC BY 4.0).

http://creativecommons.org/licenses/by/4.0/

c) (i) Open Access

\begin{abstract}
Both Ecosystem-based Adaptation (EbA) and Payment for Ecosystem Services (PES) have a wide range of strategies that include different economic instruments for nature conservation. Although the generation and maintenance of payment for hydrologic ecosystem services (Water-PES) is expanding in Brazil, there are difficulties in the implementation of projects. Due to the complexity and non-linearity of the hydrological processes, also affecting both EbA and Water-PES goals, monitoring qualiquantitative aspects of streams have been here addressed as a useful management tool. This study presents the Hydrological Monitoring Plan (HMP) of the Water Producer/PCJ project, operating between 2009-2014, in order to: 1) evaluate the impact of project actions under water quali-quantitative aspects; and 2) promote the incorporation of HMP's elements in water resources management. HMP of the Water Producer/PCJ project has been implemented following the conditions for efficiency (baseline, long-term scale compatible with the actions of the project, in the experimental and reference watersheds). In addition, HMP is being implemented from upstream to downstream in catchments with areas ranging from 17 to $130 \mathrm{~km}^{2}$. This proposal favors the quantification and valuation of hydrologic services that could be assessed by ecohydrologic monitoring and modeling. Thus, we look forward to the consolidation of the Brazilian information system of water resources, the reduction of modeling uncertainties and integrated assessment of the consequences of landuse/land-cover change that strongly impact goals of EbA and Water-PES initiatives.
\end{abstract}

\section{Keywords}

Ecohydrological Monitoring, Brazilian Water Producer/PCJ Project, Hydrologic Services, Quali-Quantitative Aspects of Water Resources 


\section{Introduction}

The hydrologic ecosystem services, hereafter referred as hydrologic services, are the ecohydrologic natural processes arising from river flow dynamics and flow/riparian areas interaction which benefit people. These processes can, for example, improve water quality, regulate flood risks, increase recreational opportunities and create positive socioeconomic effects. Hydrologic services are quantified by quali-quantitative river monitoring. The Active River Area assessment [1] [2] methods can also be applied in the monitoring, as it considers the hydrologic connectivity and natural variability of riparian areas from the headwaters downstream to the catchment's outlet. Several authors have proposed definitions of payments for ecosystem services (PES) for the water resources or biodiversity protection, and carbon sequestration. Some authors define them as compensation for the benefits people obtain from ecosystems [3]. They are considered voluntary transactions in which a determined ecosystem service is purchased from a provider under the condition of securing the service provision [4]. [5] added the generation of positive externalities to the concept. [6] define them as the availability (or utility) of ecosystems for human needs. Furthermore, [7] relate PES with policy prospects and partnerships to align decision-making on land use. The definition of PES is sufficiently broad to encompass various economic instruments for environmental conservation [8] [9].

On the one hand, ecohydrological processes [10] [11] [12] interact nonlinearly. These processes affect biodiversity and primary production, and define the river regime, environmental flows and hydrologic ecosystem services [13]. Specifically for Water-PES, the potential provision of these services depends on the water-balance equilibrium of flows and pollution loads [14]. On the other hand, Water-PES are dependent on the relationship between availability and demand, variable according to both 1) natural fluctuations or induced by the impacts of human activities, and 2) functional and distribution conditions of the ecosystems in the watersheds. In this interaction, the "water + climate" composition is the main sustainability element for water security.

Generally, agricultural water uses are classified as "insignificant withdrawals", as defined in Brazilian legislation [15] [16] and recognized by Watershed Committees, can add another stress factor to water security. The "insignificant uses" demand a detailed study on water withdrawal and wastewater disposal of small rural properties to assess possible impacts to water security in these critical sub basins, strategic for public supply and for ecosystem services delivery.

The objective of the Water Producer/PCJ project freshwater monitoring is to evaluate ecosystemic impacts from a project based in the PES economic instruments to stimulate the use of voluntary conservation practices for soil conservation, forest restoration in Permanent Preservation Areas (APP), and conservation of remaining forest fragments. Water Producer/PCJ project is a pioneering pilot project in Sao Paulo state which includes public-private partnerships [17], with the aim of providing support for larger scale projects [18]. The specific objectives of the Hydrological Monitoring Plan (HMP) of Water-PES projects are:

- To characterize the natural freshwater quality of the catchments covered by the project 
that aims to contribute to the implementation of the respective PCJ/River Basin Plan.

- Determine the baseline of the project based on land-use/land-cover information, hydrologic data, questionnaires with information on environmental and socioeconomic perception;

- Assess hydrologic conditions and trends, concentrations of monitored pollutants and the expected limits for the re-systematization of water bodies;

- Identify areas with significant water quality changes;

- Give valuable inputs for the formulation of mitigating actions for the prevention and control of soil and water pollution;

- Assess the effectiveness of project actions and long-term adaptation strategies;

- Provide consistent information to assess the maintenance and future expansion of the project or its replication in other Brazilian regions through new PES public policies;

- Encourage the creation and maintenance of real-time monitoring database, which are able to release environmental alerts, reducing the vulnerability ${ }^{1}$ of the watersheds and productive areas occurring there.

\section{Scope of This Work}

The objectives of this work are: 1) assess the impact of conservation actions in the Water Producer/PCJ project through the hydrological monitoring plan (HMP) with key integration to EbA and Water-PES project strategies; and 2) support the incorporation of HMP elements through water resources management tools, such as: information systems, watershed management plan, freshwater quality standards, water rights concessions and water resources use fees according to the current norms [15] [16] [20] [21].

\section{Material and Methods}

\subsection{Study Area}

The study area includes watersheds that, contribute to Piracicaba river, that along with Jundiaí and Capívari rivers, is managed within PCJ watershed committee, covering $15.304 \mathrm{~km}^{2}$. In the Sao Paulo portion of the PCJ river basin, the Water Resources Management Unit No. 5 (UGRHI-5) has $14.178 \mathrm{~km}^{2}$ (92.6\% of the basin area), and the rest of the UGRHI-5 territory (7.4\%) is located in Minas Gerais state. The PCJ basins have the higher economic development and per capita income in Brazil. However, due to the high population density ( $\left.301 \mathrm{hab} / \mathrm{km}^{2}\right)$, if compared to other Brazilian river basins, the use of this water is conflicting and eutrophication of the water sources is at an advanced stage [22]. Because of it, in the last decade, the headwaters of Atibainha and Jaguari watersheds become of strategic interest, because of their relative better water quality. The implementation of water resources user fees in the PCJ Committees in 2007 allowed part of the funds of water charging to be applied in the Water Producer/PCJ project. In mid-2013 the project area covered 252 hectares in Joanópolis and Nazaré Paulista municipalities, state of Sao Paulo. After three years of PES contracts between landowners and the financial agent from PCJ Committees (2011-2014), the project area

${ }^{1}$ Vulnerability is the state of a system exposed to risks, controlled by biophysical and socio-cultural factors at different temporal and spatial scales, combined with its responsiveness [19]. 
covered 99 hectares of soil conservation, 68 hectares of forest restoration and 391 hectares of forest conservation [23].

Taking into account the availability of previous hydrologic information and the need of restoration in these microwatersheds, the catchments being part of the HMP activities were previously selected: Cancã $\left(97 \mathrm{~km}^{2}\right)$ and Cachoeira dos Pretos $\left(130.4 \mathrm{~km}^{2}\right)$, in Joanópolis, and Moinho $\left(17.6 \mathrm{~km}^{2}\right)$ in Nazaré Paulista (Figure 1).

\subsection{Methods}

Regarding the self-purification ${ }^{2}$ process of rivers and streams, hydrological monitoring is critical for understanding the changes of pollutant concentrations in different seasons [24] [25] [26]. To assess self-purification characteristics, quali-quantitative parameters were included into the HMP of the headwaters of the main tributary rivers to Sistema Cantareira: Jaguari $\left(1000 \mathrm{~km}^{2}\right)$, Cachoeira $\left(392 \mathrm{~km}^{2}\right)$ and Atibainha $\left(315 \mathrm{~km}^{2}\right)$ to find possible seasonal changes of pollutants or macronutrients (see Table 1).

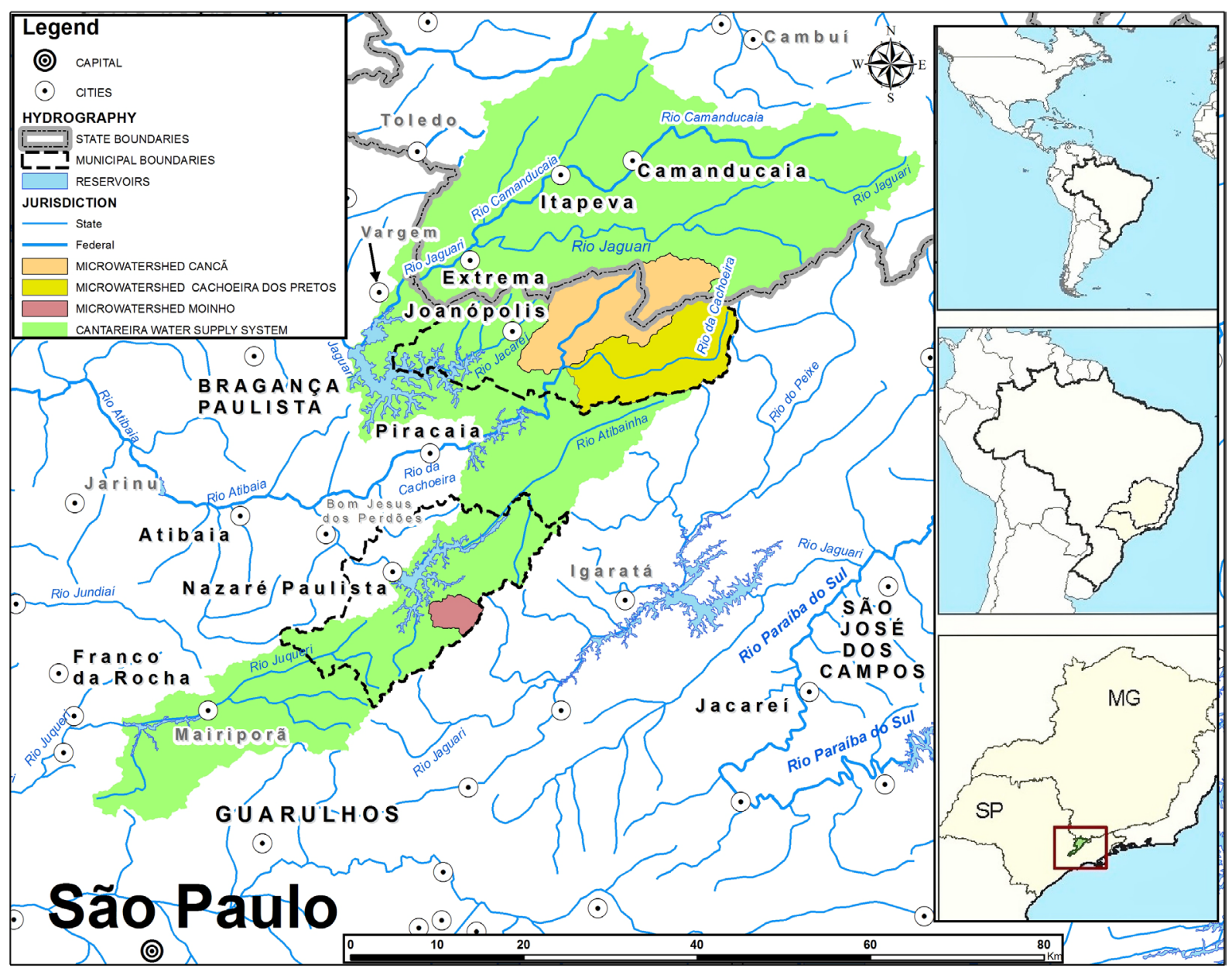

Figure 1. Catchments of the water producer/PCJ pilot project.

${ }^{2}$ Self-purification is the restoration of the water quality after the changes induced by the discharge of effluents. The main parameters changed due to self-purification are the dissolved oxygen concentrations, biochemical oxygen demand (BOD) and pathogenic microorganisms, river contaminants [24]. 
Table 1. Surface HMP methods with key variables for ecohydrological assessments of EbA and Water-PES projects. Source: adapted from [34].

\begin{tabular}{|c|c|c|c|}
\hline Method & Key variable & Method & Unit \\
\hline \multirow{9}{*}{$\begin{array}{l}\text { Systematic } \\
\text { monitoring }\end{array}$} & $\mathrm{pH}$ & 40,500 $\mathrm{H}^{+}$-B-Electrometric method & -- \\
\hline & Electrical conductivity & 2510 B-Laboratory method & $\mu \mathrm{mho} \cdot \mathrm{cm}^{-1}$ \\
\hline & Turbidity & $2130 \mathrm{~B}$ & NTU \\
\hline & Water Temperature & 2550 B-Field and laboratory method & ${ }^{\circ} \mathrm{C}$ \\
\hline & Water level & Limnimetric scale & $\mathrm{m}$ \\
\hline & Air temperature & -- & ${ }^{\circ} \mathrm{C}$ \\
\hline & Relative humidity & Vapor pressure-temperature relationship & $\%(\mathrm{~Pa} / \mathrm{Pa})$ \\
\hline & Precipitation & Volumetric & $\mathrm{mm}$ \\
\hline & Radiation & Net radiation & $\mathrm{W}$ \\
\hline \multirow{12}{*}{$\begin{array}{c}\text { Episodic } \\
\text { Monitoring } \\
\text { (seasonal } \\
\text { campaigns) }\end{array}$} & Flow rate & Bathymetry and propeller; ADCP-Doppler & $\mathrm{m}^{3} \cdot \mathrm{s}^{-1}$ \\
\hline & Dissolved Oxygen (DO) & 4500 OG-Electrode with membrane & $\mathrm{mgO}_{2} \cdot \mathrm{L}^{-1}$ \\
\hline & Chemical Oxygen Demand (COD) & $\begin{array}{l}5220 \text { D-Colorimetric closed reflection } \\
\text { method }\end{array}$ & $\mathrm{mgO}_{2} \cdot \mathrm{L}^{-1}$ \\
\hline & Biochemical Oxygen Demand (BOD) & $5210 \mathrm{~B}-\mathrm{BOD}$ test 5 days & $\mathrm{mgO}_{2} \cdot \mathrm{L}^{-1}$ \\
\hline & Total Dissolved Solids (TDS) & 2540 C-Porcelain capsule & $\mathrm{mg} \cdot \mathrm{L}^{-1}$ \\
\hline & Total Suspended Solids (TSS) & 2540 D-Membrane & $\mathrm{mg} \cdot \mathrm{L}^{-1}$ \\
\hline & Total Nitrogen & 4500 NB-Macro Kjeldahl & $\mathrm{mg} \cdot \mathrm{L}^{-1}$ \\
\hline & Nitrate $\left(\mathrm{NO}_{3}\right)$ & $4500 \mathrm{NO}_{3}$-B-Spectrophotometric method & $\mathrm{mg} \cdot \mathrm{L}^{-1}$ \\
\hline & Nitrite $\left(\mathrm{NO}_{2}\right)$ & $4500 \mathrm{NO}_{2}$-B-Colorimetric method & $\mathrm{mg} \cdot \mathrm{L}^{-1}$ \\
\hline & Nitrogen Ammonia $\left(\mathrm{NH}_{3}\right)$ & $4500 \mathrm{NH}_{3}$-C Titration method & $\mathrm{mg} \cdot \mathrm{L}^{-1}$ \\
\hline & Total phosphorus & 4500 P-E-Ascorbic acid & $\mathrm{mg} \cdot \mathrm{L}^{-1}$ \\
\hline & Escherichia coli & 9223 B-Enzyme-substrate test & $\mathrm{CFU} / 100 \mathrm{~mL}^{-1}$ \\
\hline
\end{tabular}

Land-use/land-cover (LULC) change impact ecosystems and the services they provide in diverse scales. Regarding hydrological services, LULC change is one of the most significant anthropogenic pressures which change water flows and modify regulating hydrological services [10] [27] [28]. In addition, slope, topography, soil development and soil depth are also terrestrial characteristics of the watersheds which impact hydrologic services, as reported by [29] [30], among others.

The land-use/land-cover (LULC) changes of micro catchments contributing to public drinking supply are crucial for the production of water in adequate quantities and quality conditions [31]. Also, these changes lead to risks of potential water crisis with impacts on vulnerable ecosystems and people [32] [33].

To verify how anthropic activities for one hand and Water-PES actions, on the other hand, can further influence environmental quality, HMP investigates the past conditions (year 2003) and near current conditions (year 2010) of LULC (Figure 2). This diagnosis helps understanding the current environmental quality of catchments for prospective EbA initiatives using this HMP. Also, FMP improves the monitoring of Water Producer/PCJ project, as auxiliary tool in planning and selecting quali-quantitative 


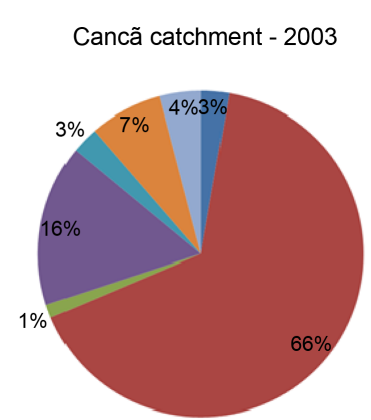

Cachoeira dos Pretos catchment - 2003

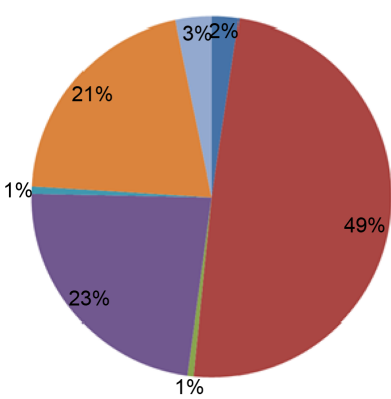

Moinho catchment - 2003

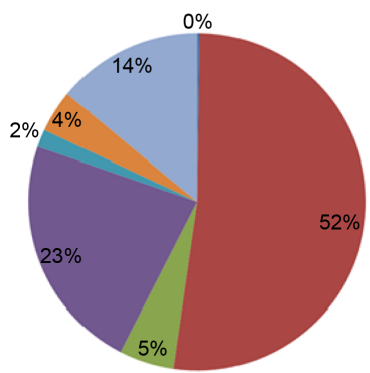

Agriculture

Sparse human settlement

Bare soil

Secondary vegetation II
Cancã catchment - 2010

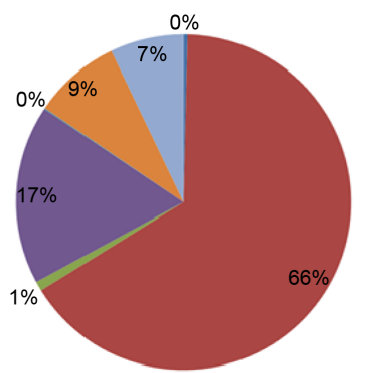

Cachoeira dos Pretos catchment - 2010

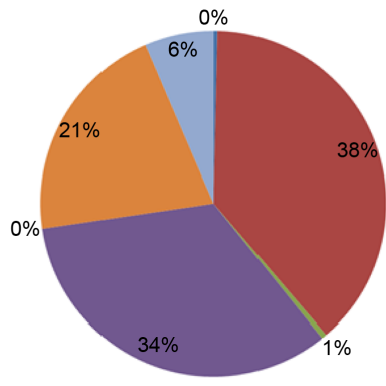

Moinho catchment - 2010

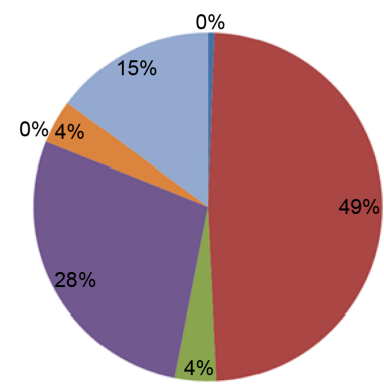

Anthropic area

Reforestation

- Secondary vegetation I

Figure 2. Past (2003) and near present (2010) soil cover in catchments located in headwaters of Cantareira water supply system, which drainage areas are involved in water producer/PCJ project. Secondary vegetation I: old forests, with at least 30 years. Secondary vegetation II: forests with age below 30 years. Anthropic area encompasses pasture. Data source: Socioambiental institute.

sampling sites under LULC change, regarding water yield, seasonal flow-with-load regimes and ecohydrological variables. After 6 Hydro monitoring working group meetings and several studies, we conclude that specific conditions are crucial for effectivity of the hydrological monitoring. See Section 4.1.

Comparing LULC in years 2003 and 2010, regarding soil uses, Figure 2 shows that the anthropic use is higher in Cancã catchment (66\%) than in Moinho (around 50\%) and Cachoeira dos Pretos catchments (49\% in 2003 and 38\% in 2010). There is a trend to reduce agriculture areas in Cancã and Cachoeira dos Pretos catchments, which is not 
observed in Moinho catchment. Both in Cancã and in Cachoeira dos Pretos catchments part of agriculture has been replaced by reforestation. This issue is relevant for the recovery of ecosystem since both catchments are located in Cachoeira basin. Joanópolis municipality, where larger part of Cachoeira basin is located, has $80 \%$ of its area occupied by pasture, agriculture, and bare soil [31].

Although the Water Producer/PCJ project started in 2009, HMP is at an early implementation stage, which enhanced since 2013 onwards. We believe that this HPM enables posing questions such as: Do Water-PES' actions of the Water Producer/PCJ project improve and conserve the water quality and water flow regulation in the headwaters under LULC changes of the Cantareira Water Supply System? To address answers through EbA methods, ecohydrologic experiments and modeling are needed. Using field campaigns (episodic monitoring) and official database (systematic monitoring) from agencies engaged in HMP at PCJ committees, i.e. CETESB, DAEE, SABESP, INMET, ANA, CODEAGRO, CEMADEN, human impacts on quali-quantitative freshwater regimes are verified [14] [34] [35]. Furthermore, possible positive impacts of Water-PES project's conservation actions are viable to screen explicitly through HMP. Further details about field evidences of episodic HMP and ecohydrologic modeling with EbA scenarios are, respectively, in [36] and [37].

\section{Results and Discussion}

From the EbA approach, the Integrated Group of River Basins (Núcleo Integrado de Bacias Hidrográficas, NIBH) of the Sao Carlos School of Engineering, University of Sao Paulo with support from The Nature Conservancy (TNC), drafted a HMP proposal for Water Producer/PCJ project based on the document "Water and Soil Monitoring Protocol-Water Producer Program" (Diederichsen et al., in press). This HMP is in accordance with the National Plan for Water Quality (PNQA) of Brazilian National Water Agency (ANA), and with part of the hydrological monitoring in Water Funds' case studies in Latin America, organized by [38]. The HMP was presented to Water Producer/PCJ project's partners in a Workshop held in May 2013 in Atibaia municipality, Sao Paulo state. Then, we fully presented an initial version of this HMP plan at the XX Brazilian Simposium of Water Resources [39].

Metrics and indicators for evaluating PES effectivity are essential. Regarding the Water Producer/PCJ project, the HMP, especially Figure 2, seeks to help assessing the Water-PES implementation. Examples of these metrics or indicators can be: 1) PES project area/watershed area; 2) benefited population $3 /$ total watershed population; 3) applied financial resources related to benefits generated (lower water treatment costs and higher water yield, for example). Thus, this HMP can help obtaining short- and long-term Water-PES project performance, a scientific guideline for PES according to [40].

Then, to apply the quali-quantitative monitoring plan, which can further allow the ${ }^{3}$ Benefited population, also called PES beneficiaries, here means the number of inhabitants living in 1) the PES project areas, 2) downstream the PES project area, and/or 3) regions with flow transfers from PES project areas. 
assessment of PES implementation, some requirements are needed to monitoring sites selection. The first monitoring sites were determined based on scale compatible with Water-PES actions, aspects related to LULC changes and comparing EbA-reference catchments to catchments targeted of conservation actions of Water-PES in the scope of Water Producer/PCJ project (Figure 3 and Table 2). Local LULC change allowed elucidating the complexity of soil uses verified from field in loco diagnosis of water yield at these headwaters. Field evidences showed LULC relevant on watersheds of public supply, because local modifications impacted water quantity and quality. Freshwater quality was jeopardizing because of agrochemicals used in conventional agriculture, and erosion process due to urbanization. Also, urbanization and economic activities
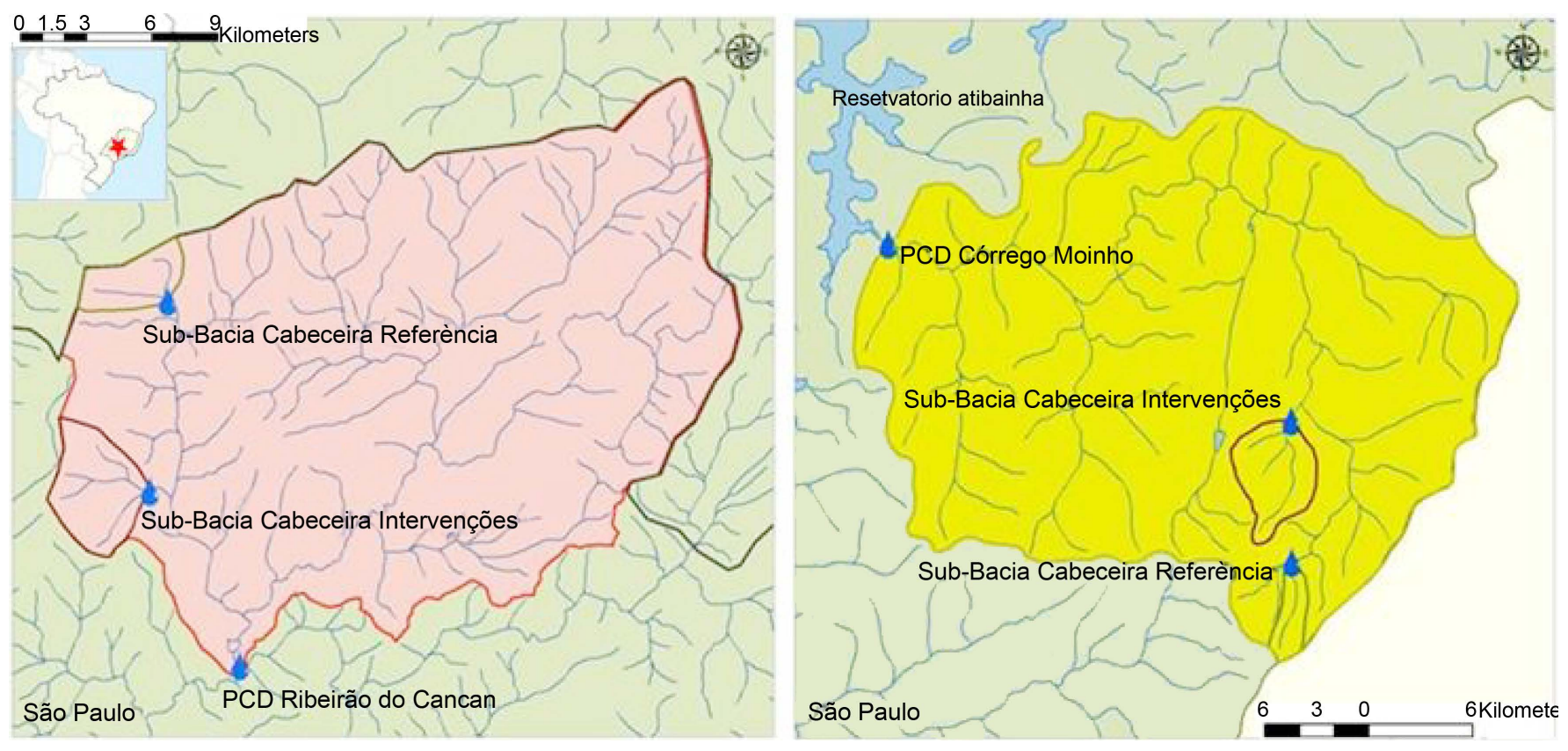

Figure 3. Selected water-PES sites for the HMP of the water producer/ PCJ project. Left side: monitoring sites in the Cancã catchment, Joanópolis municipality, Sao Paulo state. Right side: monitoring sites in the Moinho catchment, Nazaré Paulista city, Sao Paulo state.

Table 2. Location of dataloggers installed in catchments of the water producer/PCJ project.

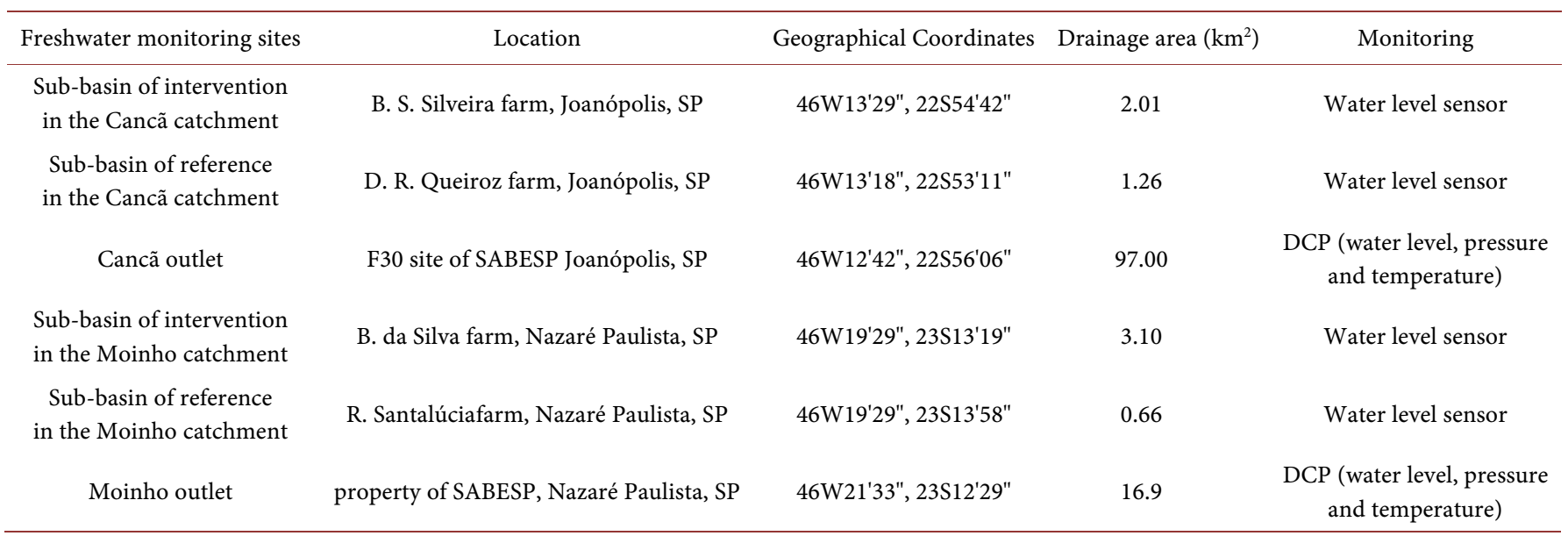


were performed at unappropriated areas, without planning, damaging water yield, as pointed by [31].

We found erosion field evidences in these subtropical Oxisols during in loco visits were expressive as previously related by [22]. [41] related field evidences of surface flow water pathways related to erosion patterns in catchment laying on Oxisols with erosion rates of approximately $1 \mathrm{t} /$ ha per year and variable concentration of suspended solids. This evaluation justifies the monitoring of water flows and erosion on the watershed scale.

In mid-2013, the monitoring includes two Data Collection Platforms (DCP), four fluviometric scales and two barologgers. Barometric readings are synchronized with the level readings. The equipment purchase, installation and maintenance are the responsibility of ANA, TNC, WWF and EESC/USP. The location of equipments installation was determined by the Hydrologic Monitoring Working Group (GTM-Hydro) of the Water Producer/PCJ project and it is shown in Table 2 and Figure 4.

\subsection{Effective Monitoring Conditions}

\section{1) Baseline conditions}

Monitoring should be implemented preferably before start of LULC interventions. This is necessary to identify the baseline and to serve as a temporal analysis reference. The baseline can identify possible positive changes as a result of the expansion of ecosystem services promoted by the project, as well as ecohydrologic variables related, thereby
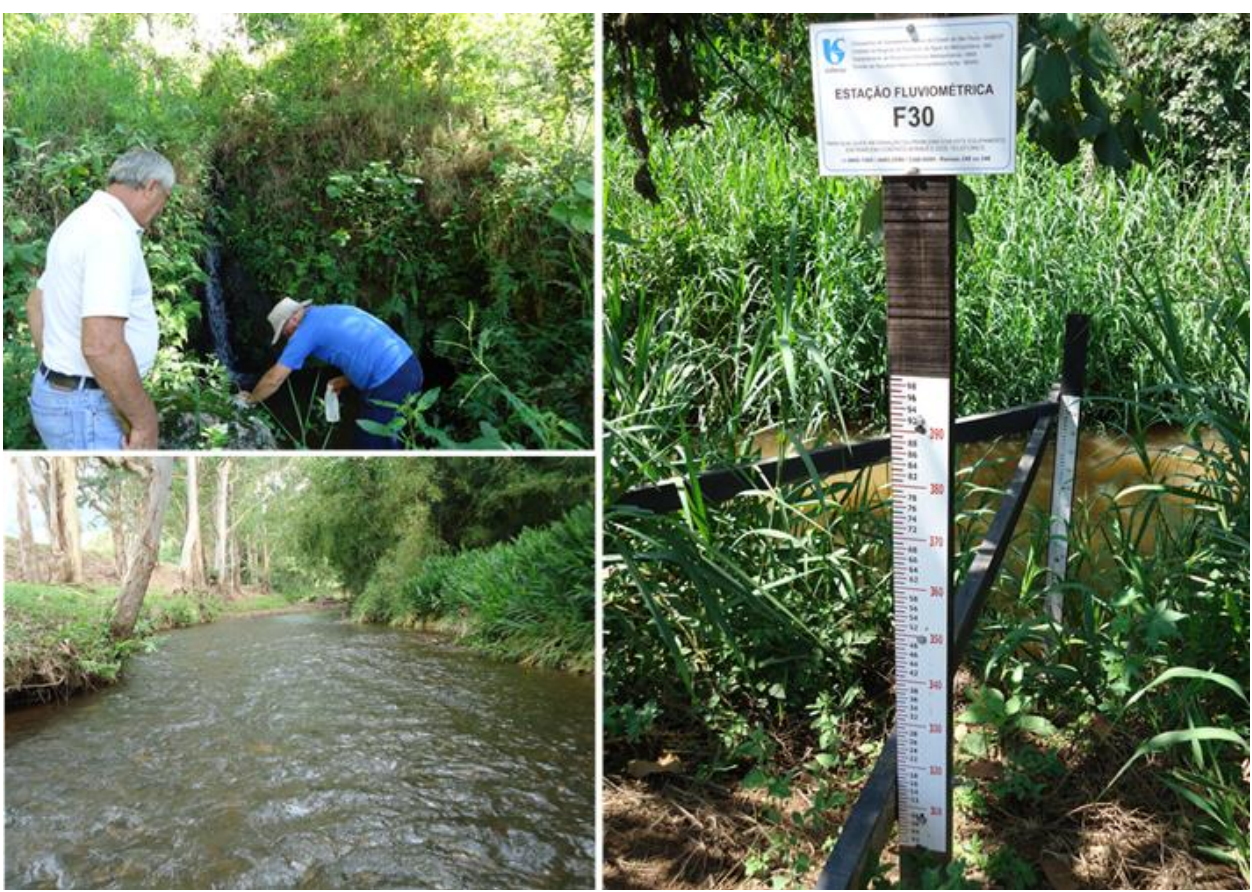

Figure 4. Selected locations for the freshwater monitoring of the water producer/PCJ project. Upper left photo: sampling in the Cancã reference catchment; Lower left photo: place selected for the limnimetric scale installation in Cachoeira dos Pretos catchment; Right side photo: Cancã outlet. Photos: Denise Taffarello, December, 2012. 
encompassing the integration of quali-quantitative variables.

\section{2) Long-term monitoring}

The PES pilot projects should necessarily have long-term monitoring. Regarding both quali-quantitative aspects, "long-term" is understood as a horizon span ranging between 30 and 50 years, to consolidate legal and socio-economic elements as well as LULC change. An operational framework is required to document the changes for the regular storing and analysis of the field data collection.

\section{3) Scale compatibility with project actions}

It is crucial to have a significant geographic scope, integrating PES interventions at local scales, which will promote the maintenance and recovery of native soil vegetation in the river basin scale, because it is assumed that the monitoring data obtained will reflect the expected benefits from the actions through EbA. However, it is not easy to implement forest restoration and soil conservation activities in a significant portion of the basin and within a short period of time.

Thus, it is recommended to implement the monitoring structure in the catchment scales scale, when there is a sufficient range of land use changes, to enable perceiving in the short term the impacts on water quality and flow regime.

\section{4) Reference and intervention catchments}

The improvement and maintenance of the water quality conditions and hydrologic regime will be included in the monitoring of catchments where the forest cover has changed significantly, named as "intervention" catchment. A property located in the same catchment was selected (which has the same physiographic, climatic and environmental characteristics), but with no significant change in the original vegetation cover (minimum of $80 \%$ of native vegetation cover), named as "reference" catchment.

\subsection{Types of Monitoring}

\section{Spatial monitoring (nested catchment experiment)}

For the experimental catchments, monitoring quali-quantitative control sites of water yield is selected through Nested Catchment Experiment method (NCE) [41] [42], as follows. Headwater reference catchments of 1 st or 2 nd order, with no forest restoration and soil conservation interventions are compared to headwater catchments with project interventions. Both inside the same basins of 3rd order.

\section{Temporal monitoring}

The variables have to be collected 1) systematically (quantitative), with time interval as a fraction of the observed time of concentrations, i.e., the average response time of a rainfall-runoff process [43] [44]; and 2) episodic (qualitative) based on seasonal campaigns [45] [46] [47]. Specifically, in the Water Producer/PCJ project hydrological monitoring, we set up the time-step of continuous monitoring variables of water level, pressure and temperature each 15 minutes. The seasonal field campaigns have chosen to be bimonthly, to investigate the seasonal dynamics of river regimes.

We also suggest using flow-load duration curves in the monitoring of the Water Producer/PCJ project, to describe the pollution loads according to flow rates, facilitating 
to visualize the quali-quantitative natural behavior of freshwater resources [14] [35] [48]. Flow and load duration curves demonstrate changes in land use or climate in the watersheds [13]. Studying flow-load duration curves under different scenarios, for example, including EbA or different rates of wastewater treatment, allows evaluating hydrologic services provided by Water-PES, addressing a more effective and reliable water security.

\section{Conclusions \& Recommendations}

Regarding the Water Producer/PCJ project, the following actions can be envisaged with the freshwater monitoring here proposed: 1) Complement the water resources information system in the PCJ Watersheds Committee; 2) Incorporate the information system in ANA's database (PNQA), using updated information from CETESB and DAEE, and CEMADEN (www.cemaden.gov.br); 3) Estimate the detailed water balance in experimental watersheds; 4) Anticipate the frequency curves of flow and loads; 5) Assess water availability for water use permission; 6) Anticipate the balance of pollutant loads and the re-categorizing of water bodies; 7) Estimate the green, blue and gray water flows, and their water footprint (according to [49]); 8) Identify and prioritize lowsustainability critical areas by comparing availabilities and demands within the PCJ watersheds; 9) Improve the information quality of user registration; 10) Support adaptation strategies for potential climate changes and mitigation measures for the medium and long term; 11) Identify possible changes in the quality and quantity of water resources resulting from the conservation actions of the Water Producer/PCJ project; 12) Strengthen institutional arrangements in PES projects undertaken in the River Basin Committee.

Our study consists of a new hydrological monitoring proposal with variables that can be quantified in the flow and load duration curves. Advancing the monitoring of Water-PES projects contributes toward consolidating the Brazilian information system on water resources, improving hydrologic models, and updating the integrated environmental assessment. Besides, the hydrological monitoring here proposed can help obtaining short- and long-term Water-PES project performance, a scientific guideline for PES according to [40]. As a result, the real sustainability of ecosystem services can be better assessed and valued in the long-term.

\section{Acknowledgements}

This work was supported by the Sao Paulo Research Foundation grants \#2012/22013-4, "Assessing Hydrologic Services based on Grey Water Footprint: a case study in the headwaters of Cantareira Water Supply System", and \#2008/58161-1, “Assessment of Impacts and Vulnerability to Climate Change in Brazil and Strategies for Adaptation Options".

\section{References}

[1] Smith, M.P., Schiff, R., Olivero, A. and Mac Broom, J. (2008) The River Active Area: A Conservation Framework for Protecting Rivers and Streams. The Nature Conservancy 
(TNC), Arlington.

[2] Palmer, M.A., Lettenmaier, D.P., Poff, N.L., Postel, S.L., Richter, B. and Warner, R. (2009) Climate Change and River Ecosystems: Protection and Adaptation Options. Environmental Management, 44, 1053-1068. http://dx.doi.org/10.1007/s00267-009-9329-1

[3] Costanza, R., d’Arge, R., de Groot, R., Farber, S., Grasso, M., Hannon, B., Limburg, K. Naeem, S., O’Neill, R.V., Paruelo, J., Raskin, R.G., Sutton, P. and Van Den Belt, M. (1997) The Value of the World's Ecosystem Services and Natural Capital. Nature, 387, 253-260. http://dx.doi.org/10.1038/387253a0

[4] Wunder, S. (2006) The Efficiency of Payments for Environmental Services in Tropical Conservation. Conservation Biology, 21, 48-58. http://dx.doi.org/10.1111/j.1523-1739.2006.00559.x

[5] Pagiola, S. and Platais, G. (2007) Payments for Environmental Services: From Theory to Practice. World Bank, Washington.

[6] Balvanera, P., et al. (2012) Ecosystem Services Research in Latin America: The State of the Art. Ecosystem Service: Science, Practice and Policy, 1, 56-70.

[7] Muradian, R. and Rival, L. (2012) Between Markets and Hierarchies: The Challenge of Governing Ecosystem Services. Ecosystem Services. Science, Policy and Practice, 1, 93-100.

[8] Pagiola, S., von Glehn, H.C. and Taffarello, D. (2013) Brazil's Experience with Payments for Environmental Services. PES Lessons for REDD+ Workshop, San José.

[9] Pagiola, S., von Glehn, H.C.Q. and Taffarello, D. (Org.) (2013) Experiências de Pagamentos por Serviços Ambientais no Brasil [Payment for Environmental Services experiences in Brazil]. Secretaria de Estado do Meio Ambiente/Banco Mundial, São Paulo, 336 p.

[10] Brauman, K.A. (2015) Hydrologic Ecosystem Services: Linking Ecohydrologic Processes to Human Well-Being in Water Research and Watershed Management. Wires-Water, 2, 345358. http://dx.doi.org/10.1002/wat2.1081

[11] Zalewski, M. (2010) Ecohydrology for Compensation of Global Change. Brazilian Journal of Biology, 70, 689-695. http://dx.doi.org/10.1590/S1519-69842010000400001

[12] Mendiondo, E.M. (2008) Challenging Issues of Urban Biodiversity Related to Ecohydrology. Brazilian Journal of Biology, 68, 983-1002. http://dx.doi.org/10.1590/S1519-69842008000500007

[13] Taffarello, D. and Mendiondo, E.M. (2013) A New Perspective on Environmental Flows of Brazilian Catchment under Change: Multidimensional Approach of Qualiquantitative Frequency Curves for Hydrologic Ecosystem Services Assessment. Water in the AnthropoceneGWSP, Conference, Bonn, Alemanha.

[14] Cunha, D.G.F., Calijuri, M.C. and Mendiondo, E.M. (2012) Integração entre curvas de permanência de quantidade e qualidade da água como uma ferramenta para a gestão eficiente dos recursos hídricos. Engenharia Sanitaria e Ambiental, 17, 369-376. http://dx.doi.org/10.1590/s1413-41522012000400003

[15] Brasil (1997) Federal Law no 9433. National Water Resources Policy and the National Water Resources Management System, Brasília. http://www.planalto.gov.br/ccivil 03/leis/19433.htm

[16] Sao Paulo (1991) State Water Law No. 7.663. Guidelines for State Water Resources Policy and for Integrated System of Water Resources Management. http://www.sigrh.sp.gov.br/legislacaoderecursoshidricos

[17] Mazzocato, C., Taffarello, D. and Mendiondo, E.M. (2013) Uso da Ecohidrologia para monitoramento do PSA-Água no estado de São Paulo. 20th Simposio Brasileiro de Recursos Hídricos, Bento Gonçalves, 17-22 Novembre 2013, 509. 
[18] Padovezi, A., Viani, R.A.G., Kubota, U., Taffarello, D., Faria, M., Bracale, H., Ferrari, V. and Carvalho, F.H. (2013) Produtor de Água na Bacia Hidrográfica PCJ. In: Pagiola, S., von Glehn, H.C. and Taffarello, D., Eds., Experiências de Pagamentos por Serviços Ambientais no Brasil, Secretaria de Estado do Meio Ambiente, São Paulo, 99-114.

[19] Interdisciplinary Climate Investigation Center (INCLINE) (2013) Conceito de Vulnerabilidade. Oficina Interdisciplinar Incline discussão e construção conjunta do conceito de vulnerabilidade, IAG/USP, Sao Paulo, April 2013. www.incline.iag.usp.br

[20] Sao Paulo (2005) State Water Law No. 12.183. Rules on the Charging for the Water Resources Uses by Industrial and Urban Users.

http://www.sigrh.sp.gov.br/legislacaoderecursoshidricos

[21] Sao Paulo (2006) State Decree No. 50.667. Regulates Provisions of Law No. 12,183 of December 29, 2005, Which Deals with Charging for the Water Resources Uses in the State of Sao Paulo, and Gives Related Measures. http://www.sigrh.sp.gov.br/legislacaoderecursoshidricos

[22] COBRAPE (2011) Plano das Bacias Hidrográficas dos Rios Piracicaba, Capivari e Jundiaí 2010-2020 (Com Propostas de Atualização do Enquadramento dos Corpos d'Água até o Ano de 2035).

[23] Taffarello, D., Calijuri, M.C., Viani, R.A.G., Marengo, J.A. and Mendiondo, E.M. (2015) Hydrological Services in the Atlantic Forest, Brazil: An Ecosystem-Based Adaptation through Ecohydrological Monitoring. Manuscript Submitted for Publication.

[24] Von Sperling, M. (2005) Introdução à qualidade das águas e ao tratamento de esgotos. 3rd Edition, Departamento de Engenharia Sanitária e Ambiental, Universidade Federal de Minas Gerais, Belo Horizonte, 452 p.

[25] Bottino, F., Ferraz, I.C., Mendiondo, E.M. and Calijuri, M.C. (2010) Calibration of QUAL2K Model in Brazilian Micro Watershed: Effects of the Land Use on Water Quality. Acta Limnologica Brasiliensia, 22, 474-485. http://dx.doi.org/10.4322/actalb.2011.011

[26] Mendiondo, E.M. (2008) Challenging Issues of Urban Biodiversity Related to Ecohydrology. Brazilian Journal of Biology, 68, 983-1002. http://dx.doi.org/10.1590/S1519-69842008000500007

[27] Rounsevell, M.D.A., Pedroli, B., Erb, K.-H., Gramberger, M., Busck, A.G., Haberl, H., Kristensen, S., Kuemmerle, T., Lavorel, S., Lindner, M., Lotze-Campen, H., Metzger, M.J., Murray-Rust, D., Popp, A., Pérez-Soba, M., Reenberg, A., Vadineanu, A., Verburg, P.H. and Wolfslehner, B. (2012) Challenges for Land System Science. Land Use Policy, 29, 899-910. http://dx.doi.org/10.1016/j.landusepol.2012.01.007

[28] Daily, G.C., Alexander, S., Ehrlich, P.R., Goulder, L., Lubchenco, J., Matson, P.A., Mooney, H.A. and Odwell, G.M. (1997) Ecosystem Services: Benefits Supplied to Human Societies by Natural Ecosystems. Issues in Ecology, 1, 1-18.

[29] Koschke, L., Lorz, C., Fürst, C., Lehmann, T. and Makeschin, F. (2014) Assessing Hydrological and Provisioning Ecosystem Services in a Case Study in Western Central Brazil. Ecological Processes, 3, 2. http://dx.doi.org/10.1186/2192-1709-3-2

[30] Terrado, M., Acuna, V., Ennaanay, D., Tallis, H. and Sabater, S. (2013) Impact of Climate Extremes on Hydrological Ecosystem Services in a Heavily Humanized Mediterranean Basin. Ecological Indicators, 37, 199-209. http://dx.doi.org/10.1016/j.ecolind.2013.01.016

[31] Whately, M. and Cunha, P. (2007) Cantareira 2006: Um olhar sobre o maior manancial de água da região metropolitana de São Paulo. Resultados do diagnóstico socioambiental participativo do Sistema Cantareira. Instituto Socioambiental, São Paulo, 67 p.

[32] Tundisi, J.G. and Tundisi, T.M. (2015) As múltiplas dimensões da crise hídrica. Revistausp, 21-30. http://dx.doi.org/10.11606/issn.2316-9036.v0i106p21-30 
[33] Gordon, L.J., Peterson, G.D. and Bennett, E.M. (2008) Agricultural Modifications of Hydrological Flows Create Ecological Surprises. Trends in Ecology \& Evolution, 23, 211-219. http://dx.doi.org/10.1016/j.tree.2007.11.011

[34] Rice, E.W., Baird, R.B., Eaton, A.D. and Clesceri, L.S. (Eds.) (2012) Standard Methods for the Examination of Water and Wastewater. 22nd Edition, American Public Health Association, American Water Works, Water Environment Federation, Washington DC.

[35] Taffarello, D., Mendiondo, E.M., Calijuri, M.C. and Cunha, D.G. (2013) Integrating Water Quantity and Quality for Environmental Regimes Based on Adaptive Water Resources Management and Planning under Change. GWSP Conference on Water in the Anthropocene, Bonn, 21-24 May 2013, p. 140.

[36] Taffarello, D., Mohor, G.S., Calijuri, M.C. and Mendiondo, E.M. (2016) Field Investigations of the 2013-14 Drought through Quali-Quantitative Freshwater Monitoring at the Headwaters of the Cantareira System, Brazil. Water International, 41, 776-800.

http://dx.doi.org/10.1080/02508060.2016.1188352

[37] Taffarello, D. Water Security and Ecosystem Based-Adaptation in the Headwaters of Cantareira Water Supply System, Brazil. Doctoral Thesis in Science: Hydraulics and Sanitation, Sao Carlos School of Engineering, University of Sao Paulo, Sao Paulo.

[38] Bremer, L., Vogl, A.L., de Bièvre, B. and Petry, P. (2016) Bridging Theory and Practice for Hydrological Monitoring in Water Funds. 98 p.

[39] Taffarello, D., Lombardi, R.K.S., Guimarães, J., Zaffani, A.G., Calijuri, M.C. and Mendiondo, E.M. (2013) Plano de Monitoramento Hidrológico do Projeto Produtor de Água nas Bacias PCJ. 20th Simposio Brasileiro de Recursos Hídricos, Bento Gonçalves, 17-22 Novembre 2013, 126.

[40] Naeem, S., Ingram, J.C., Varga, A., Agardy, T., Barten, P., Bennett, G., Bloomgarden, E., Bremer, L.L., Burkill, P., Cattau, M., Ching, C., Colby, M., Cook, D.C., Costanza, R., DeClerck, F., Freund, C., Gartner, T., Goldman-Benner, R., Gunderson, J., Jarrett, D., Kinzig, A.P., Kiss, A., Koontz, A., Kumar, P., Lasky, J.R., Masozera, M., Meyers, D., Milano, F., Naughton-Treves, L., Nichols, E., Olander, L., Olmsted, P., Perge, E., Perrings, C., Polasky, S., Potent, J., Prager, C., Quétier, F., Redford, K., Saterson, K., Thoumi, G., Vargas, M.T., Vickerman, S., Weisser, W., Wilkie, D. and Wunder, S. (2015) Get the Science Right When Paying for Nature's Services. Science, 347, 1206-1207.

http://www.sciencemag.org/content/347/6227/1206.full?utm campaign=email-scitoc\&utm src=email http://dx.doi.org/10.1126/science.aaa1403

[41] Mendiondo, E.M., Tucci, C.E.M., Clarke, R.T., Castro, N.M., Goldenfum, J., Chevallier, P. (2007) Space-Time Observations in Nested Catchment Experiments of Representative Basins-Experiences Gained and Lessons Learned to Help the PUB Initiative in the World's Biomes. Proceedings of the PUB Kick-Off Meeting, Brasilia, 20-22 November 2002, 164172.

[42] McDonnell, J.J., Sivapalan, M., Vache, K., Dunn, S., Grant, G., Haggerty, R. and Weiler, M. (2007) Moving beyond Heterogeneity and Process Complexity: A New Vision for Watershed Hydrology. Water Resources Research, 43, Article ID: W07301. http://dx.doi.org/10.1029/2006wr005467

[43] Tucci, C.E. (1993) Escoamento superficial. Hidrologia ciência e aplicação. Ed. da Universidade, Porto Alegre.

[44] Tucci, C.E.M. (2008) Águas Urbanas. Estudos Avançados, 22, 97-112.

http://dx.doi.org/10.1590/S0103-40142008000200007 
[45] Bieroza, M.Z., Heathwaite, A.L., Mullinger, N.J. and Keenan, P.O. (2014) Understanding Nutrient 25 Biogeochemistry in Agricultural Catchments: The Challenge of Appropriate Monitoring Frequencies. Environmental Science: Processes \& Impacts, 16, 1676-1691. http://dx.doi.org/10.1039/c4em00100a

[46] Abell, J.M., Hamilton, D.P. and Rutherford, J.C. (2013) Quantifying Temporal and Spatial variations in Sediment, Nitrogen and Phosphorus Transport in Stream Inflows to a Large Eutrophic Lake. Environmental Science: Processes \& Impacts, 15, 1137-1152. http://dx.doi.org/10.1039/c3em00083d

[47] Chiwa, M., Ide, J., Maruno, R., Higashi, N. and Otsuki, K. (2010) Effects of Storm Flow Samplings on the Evaluation of Inorganic Nitrogen and Sulfate Budgets in a Small Forested Watershed. Hydrological Processes, 24, 631-640. http://dx.doi.org/10.1002/hyp.7557

[48] Chen, D., Lu, J., Wang, H., Shen, Y. and Gong D. (2011) Combined Inverse Modeling Approach and Load Duration Curve Method for Variable Nitrogen Total Maximum Daily Load Development in an Agricultural Watershed. Environmental Science and Pollution Research, 18, 1405-1413. http://dx.doi.org/10.1007/s11356-011-0502-8

[49] Hoekstra, A.Y., Chapagain, A.K., Aldaya, M.M. and Mekonnen, M.M. (2011) The Water Footprint Assessment Manual: Setting the Global Standard. Earthscan, London, 203 p.

\section{Submit or recommend next manuscript to SCIRP and we will provide best service for you:}

Accepting pre-submission inquiries through Email, Facebook, LinkedIn, Twitter, etc. A wide selection of journals (inclusive of 9 subjects, more than 200 journals)

Providing 24-hour high-quality service

User-friendly online submission system

Fair and swift peer-review system

Efficient typesetting and proofreading procedure

Display of the result of downloads and visits, as well as the number of cited articles

Maximum dissemination of your research work

Submit your manuscript at: http://papersubmission.scirp.org/

Or contact jep@scirp.org 